\title{
NOTES ON SOME SPECIES OF COLURA (LEJEUNEACEAE, JUNGERMANNIOPSIDA), WITH DESCRIPTION OF COLURA CATARACTARUM FROM MADAGASCAR
}

\author{
T. Pócs \\ Department of Botany, Institute of Biology, Eszterházy Károly University \\ H-3301 Eger, Pf. 43, Hungary; E-mail: colura@upcmail.hu
}

(Received: 22 June 2020; Accepted: 20 July 2020)

Examination of about one hundred unidentified Colura specimens resulted in new distributional data of eleven uncommon species, C. australiensis, C. bicornis, C. calyptrifolia, C. crispiloba, C. cristata, C. heimii, C. humbertii, C. imperfecta, C. obesa, C. rhynchophora, C. saroltae and a new species of sect. Colura from Madagascar, C. cataractarum.

Key words: Africa, Australia, endemism, Fiji, Madagascar, Mascarenes, new species, phytogeography

\section{INTRODUCTION}

During the past decades I accumulated nearly one hundred unidentified specimens of the liverwort genus Colura (Dumort.) Dumort. (Lejeuneaceae) from different parts of the world, mostly from East Africa, Australia and the Fiji Islands, collected by myself, my wife and my colleagues. The identification of the material resulted in a large number of range extensions and recognition of a new species of section Colura, C. cataractarum Pócs, from Madagascar. In this paper new localities and range extensions of eleven uncommon species as well as the description of the new species are presented.

\section{RANGE EXTENSIONS}

In the present enumeration the first two digits of locality numbers refer to the year of collection, while the letters mark the different species within the same locality. The novelty of the records was mostly established using Ah-Peng and Bardat (2005) and Ah-Peng et al. $(2010 a, b)$ for Réunion, Grolle (1995) and Marline et al. (2012) for Madagascar and the Mascarenes, McCarthy (2003) for Australia, Söderström et al. (2011) for Fiji and Wigginton (2018) for continental Africa.

Colura australiensis Ast, Rev. Bryol. Lichénol. 22: 260 (1954) (Figs 1-3, 24) - Australia: Queensland, Cape Tribulation, Daintree National Park, 'Botanical 


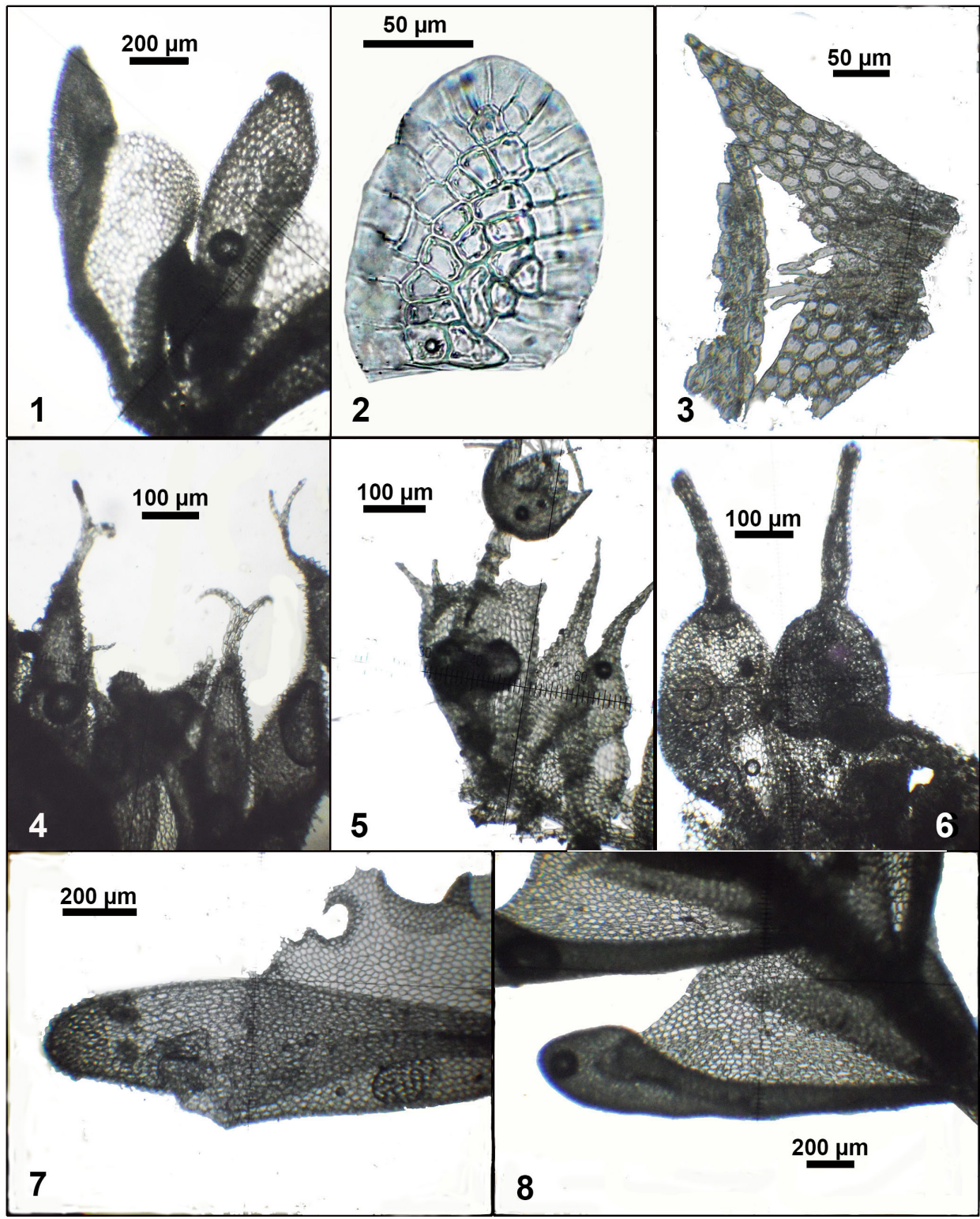

Figs 1-8. - Figs 1-3. Colura australiensis Ast (from Pócs \& Streimann 9990/C): 1 = habit, ventral view; 2 =valve; 3 = broken underleaf. - Fig. 4 . Colura bicornis Ast, habit (from Pócs, Szabó $\mathcal{E}$ 9872/AA). - Fig. 5. Colura calyptrifolia (Hook.) Dumort., habit with sporophyte (from Pócs, Szabó \& Ranaivojaona 9851/AE). - Fig. 6. Colura humbertii Ast, habit (from S. E T. Pócs 9890/ DB). - Fig. 7. Colura crispiloba Ast, lobe apex with lobule sac (from S. E T. Pócs 03269/J). -

Fig. 8. Colura saroltae Pócs, habit, ventral view (from Kis \& Pócs 9124/S) 
Circuit' along Noah Creek, on bark in mangrove forest at 1-2 m elevation, with Colura streimannii Pócs (Pócs 2015), T. Pócs, H. Streimann 9990/C (CANB, EGR). A species of sect. Harmophyllum, previously known only from the type locality on Mt Bellenden Ker in Queensland, from the Solomon Islands (Pócs 2013) and from New Caledonia (Hürlimann 1987).

Colura bicornis Ast, Rev. Bryol. Lichénol. 25: 272 (1957) (Figs 4, 23) - Madagascar, Toamasina Prov., epiphyllous in lowland rainforest at the $\mathrm{N}$ side of Fandrarazana River Estuary at 2-3 m elev., S. E T. Pócs, A. Szabó 9872/AA (EGR, TAN). Since the description of this peculiar Madagascan species of sect. Glotta with a forked sac apex (Jovet-Ast 1956) from the Moramanga-Andasibé road, only one further locality had become known, from Andringitra National Park (Pócs 1995). The species seems to prefer very wet, waterlogged rainforests.

Colura calyptrifolia (Hook.) Dumort., Recueil d'Observ. Jungerm., p. 12 (1835) (Fig. 5) - Madagascar, Antananarivo Prov., on Erica twig in a heath on the summit at the $\mathrm{N}$ end of Lake Mantasoa, near Anjorozo village, at 1,500 $\mathrm{m}$ elev., T. Pócs, A. Szabó, R. Ranaivojaona 9851/AE (EGR); Toamasina Prov. Maromizaha Forest $S$ of Andasibe National Park. Epiphyllous in a mossy cloud forest on the summit ridge of Mt Maromizaha, at 1,080-1,214 m elev., S. E T. Pócs 9890/DB (EGR, TAN). This widespread, pantropical-oceanic temperate species of sect. Colura was not previously known from Madagascar (see map in Gradstein et al. 1984).

Colura crispiloba Ast, Cryptog. Bryol. Lichénol. 4(3): 205 (1983) (Figs 7, 24) - Australia, Queensland, there are several new localities: Atherton Tableland, Cardwell Range, E slope of Mt Fisher 9 km N of Ravenshoe, at 940-1,000 m elev. Epiphyllous in disturbed rainforest, Pócs, Streimann 99114/AK. This place is not far from its type locality in Kirrima State Forest. Paluma Range: McClelland's Lookout at the E side of the village and also in the garden of A. \& W. Cairns in Paluma village, in the opening of a rainforest rich in epiphytes, at $900 \mathrm{~m}$ alt., on bark, T. Pócs 9976/A (CANB, EGR); S. E T. Pócs 01109/W (BRI, EGR). Main Coast Range, Mt Lewis W of Rumula, SW slope of the summit at 951 m elev., on decaying twigs, S. \& T. Pócs 01085/F (EGR, BRI). A new Fiji locality: Viti Levu Island, SW ridge of Mt Tamanivi (Mt Victoria), at $800 \mathrm{~m}$ elev., epiphyllous in cloud forest, S. \& T. Pócs 03269/J (EGR). According to our present knowledge this is an Australasian-Pacific species restricted to Queensland and to Viti Levu in the Fiji Islands (Jovet-Ast 1983, Pócs and Streimann 2006, Pócs and Eggers 2007).

Colura cristata Ast., Rev. Bryol. Lichénol. 22(3): 291 (1954) - Fiji Islands, Viti Levu Island, coral Coast, near Nabukavesi village $10 \mathrm{~km} \mathrm{~N}$ of Lombau, epiphyllous in wet lowland rainforest, $S \mathcal{E}$ T. Pócs 03261/CD (EGR). A rare species of section Harmophyllum, known only from Borneo, Java and from the Kadavu Island of Fiji. 
Colura heimii Ast, Rev. Bryol. Lichénol. 22(3): 275 (1954) (Fig. 9) - Two additions to the Réunion localities: SSW slope of Piton de la Fournaise volcano, along the trail from Gite Basse vallée to Puis Ramond and to Piton Larde, 720-1,250 m elev., on bark, G. Kis 9605/C, 9652/CQ (EGR, REU). In Mauritius the species was known from 1-2 localities only (Jovet-Ast 1976). Mauritius: Black River Gorges Nat. Park, N slope of Mt Cocotte, 710 m, on twig, D., S. $\mathcal{E}$ T. Pócs, D. Florins 9665/B (EGR, NAI). Tanzania, Morogoro District, Nguru Mts, which is part of the Crystalline Eastern Arc range: Watershed between Chogowale and Divue headwaters, $6 \mathrm{~km}$ SSE of Maskati Mission, at 1,960 m elev. On bamboo stems in montane rainforest dominated by Schefflera volkensii, Afrocrania volkensii and Podocarpus, T. Pócs, G. Kis 9129/W (EGR); Bamboo

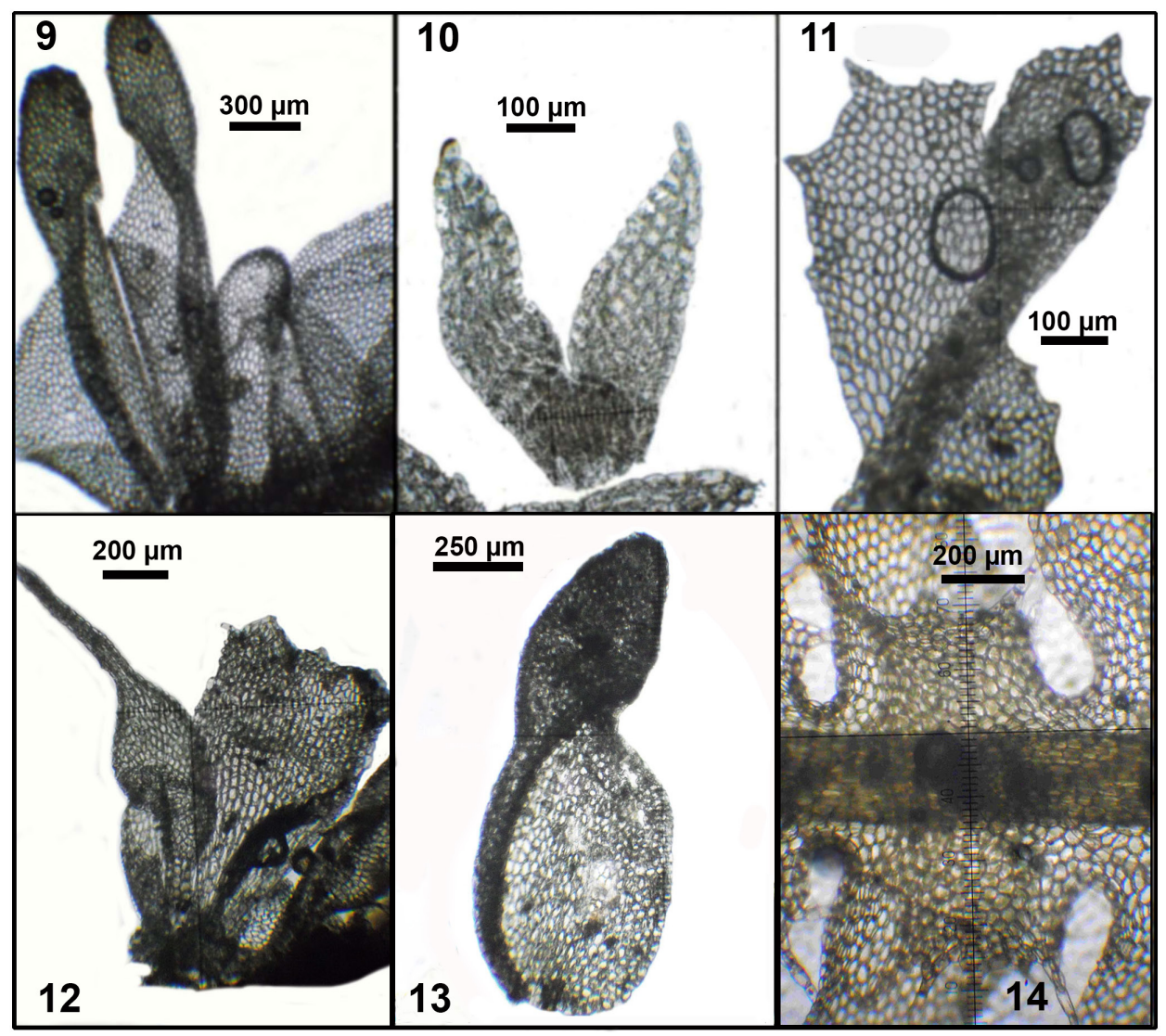

Figs 9-14. - Figs 9-10. Colura heimii Ast (from Pócs \& Kis 9129/W): 9 = habit, ventral view; $10=$ underleaf. - Fig. 11. Colura imperfecta Steph., habit, dorsal view (from Pócs \& Streimann 99117/AN). - Fig. 12. Colura rhynchophora Ast, habit with perianth (from S. E T. Pócs 03148/ BB). - Fig. 13. Colura obesa Ast, leaf, ventral view (from Pócs 6889/CF). - Fig. 14. Heteroscyphus grandistipus (Steph.) Schiffn., underleaf, ventral view (from Pócs 9473/AF) 
(Sinarundinaria alpina) forest with scattered Ocotea usambarensis trees, on the S slope of Mt Kwakungwi, $7 \mathrm{~km}$ SE of Maskati, at 1,970-2,000 m, on bamboo stem, T. Pócs, G. Kis 9135/AF and 9137/E (EGR); Dry elfin forest on the rocky top of Mt Kwakungwi, at 2,100 m, on tree bark, G. Kis, T. Pócs 9140/O and $B Q$ (EGR). Jovet-Ast $(1954,1958,1976)$ has published it and we also found it from several localities in Madagascar, where it seems to be widespread. Not so common in the island of Réunion, where it became known from 7 localities (Ah Peng et al. 2012) and was known only from 1-2 localities in Mauritius (Jovet-Ast 1976). It became known also from the Comoro Islands: Mayotte (Pócs 2010). More surprising is its discovery in continental Africa (Tanzania).

Colura humbertii Ast, Rev. Bryol. Lichénol. 22(3): 251 (1954) (Figs 6, 25) Réunion: Le Grand Brule on the E slope of Piton de la Fournaise. On lava flow of the 1931 eruption above the "Vierge au Parasol", at 50-350 m elev. On dead fern petiole in secondary Agauria-Casuarina-Erica bushes, E. Kónya, T. Pócs 9630/ZB (EGR). Tanzania: Nguru Mountains, on twigs in ericaceous heath of Kwasenjunga rock SE of Maskati Mission, at 2,010 m elev., G. Kis, T. Pócs 9111/ AX (EGR, NAI). It differs from C. tenuicornis (A. Evans) Steph. not only by the short obtuse, conical perianth horns but also the much wider, inflated lower part of lobule very quickly tapering into the half leaf long, narrow sac in contrast to the gradually narrowing sac of $C$. tenuicornis. It was known as an endemic of Madagascar and the Mascarene Islands. Jovet-Ast (1954) described it from Madagascar but later (1958) published it also from 3 localities in Réunion and Jones (1979) from Mauritius, but new for continental Africa.

Colura imperfecta Steph., Sp. Hepat. 5: 938 (1916) (Fig. 11) - Australia, Queensland edge of Atherton Tableland, Wooronooran Nat. Park, Henrietta Creek, $33 \mathrm{~km}$ WSW if Innisfail town, along the Palmerston Highway, epiphyllous in lowland rainforest with scattered Agathis robusta trees, at $375 \mathrm{~m}$ elev. T. Pócs, H. Streimann 99117/AN (CANB, EGR). A Malesian-Melanesian species distributed from the Malay Peninsula through New Guinea to the Solomon Islands. New to Australia.

Colura obesa Ast., Rev. Bryol. Lichénol. 22(2-3): 273 (1954) (Fig. 13) - New localities in Réunion: $\mathrm{S}$ slope of Piton de la Fournaise volcano from Basse Vallée at 930-1,300 m elevation, on twigs in mossy and in elfin forests, T. Pócs 9602/DD, 9612/DA (EGR). Tanzania, Uluguru Mts, summit and NE ridge of Bondwa Peak, 1,600-2,120 m elev. on leaves and on bark, T. Pócs 6889/CF, T. Pócs, M. Crosby 6844/GE (EGR, NAI). It is quite widespread in Madagascar (Jovet-Ast 1954), but had only one known locality in Réunion Island (Ah-Peng et al. 2012). After recording it from São Tomé and from Principe Island at very low altitudes, Pócs in Pócs et al. (2015: 57-59) discussed in details, supported by microphotos and a comparative table, its synonymy with the sympatric $C$. benoistii Ast. The present records are new to mainland Africa. The illustration of Jones (1979: 388, fig. 1/c) intends to depict C. dusenii Steph. This drawing 
exactly matches the drawing of the type of C. obesa Ast, provided by Jovet-Ast (1954: 274, fig. 44/4) and Pócs et al. (2015: 57, figs 3C-D), but not the illustration of $C$. dusenii in Jones (1958: 62, fig. 3/D). The latter corresponds better to the figure of C. dusenii provided by Jovet-Ast (1954: 275, fig. 45). Therefore, I suppose that several records of $C$. dusenii of Jones from continental West Africa apply also to C. obesa.

Colura rhynchophora Ast, Rev. Bryol. Lichénol. 17(1-4): 27 (1948) (Fig. 12) - Dominican Republic, prov. La Vega. Cordillera Central, Constanza, between El Convento and Valle Nuovo, epiphyllous on fern leaves in wet, mossy Pinus occidentalis forest at 2,040 m elev. S. E T. Pócs 03148/BB (EGR). A Caribbean species known from Guadeloupe (Jovet-Ast 1954), Cuba (Mustelier Martínez 2005), Jamaica (Schäfer-Verwimp and van Melick 2016), Dominica (SchäferVerwimp 1999), Martinique, Guyana, Suriname (Gradstein 1997), and Costa Rica (Eggers in Eggers et al. 2004). New to the Island of Hispaniola.

Colura saroltae Pócs, J. Bryol. 14(3): 497 (1987) (Figs 8, 24) - Tanzania, we have found new localities in the western part of Nguru Mts: on Erica twigs in the summit bush of Mafulumula Ridge, at 2,050 m, on twigs in the elfin forest at our campsite NE from Divue headwaters at 2,090 m elevation, G. Kis, T. Pócs 9124/ S, 9130/AP (EGR, NAI). This large and spectacular species preferring ericaceous twigs was hitherto known in Tanzania from the Kilimanjaro Mts (type), West Usambara Mts, E part of Nguru Mts, Rungwe Mts (Jones and Pócs 1987, Pócs 1991, Pócs 1994, Pócs and Váňa 2015); Kenya (Enroth et al. 2019, Pócs and Váňa 2015) and from Rwanda (Fischer 2013).

\section{DESCRIPTION OF THE NEW SPECIES}

\section{Colura cataractarum Pócs, spec. nova (sect. Colura)}

(Figs 15-22)

Similar to Colura ochyrana Pócs from Peru (Pócs 2019) and C. junghuhniana Steph. from Java (Stephani 1916) in the hood-like lobule sac (other members of sect. Colura have narrowly elongate horns), but differing from both species in the wider (5-8 cells wide) underleaf lobes and short, triangular perianth horns (similar to those of C. calyptrifolia). The new species is furthermore separated from C. ochyrana by the obtuse apex of the lobular sac and from $\mathrm{C}$. junghuhniana by the smooth leaf cells, without papillae.

Type: Madagascar, Prov. Fianarantsoa, Reg. Haute-Matsiatra, Andringitra Massif and National Park, on steadily irrigated granite rocks in the cataracts of the W tributary of Korokoro River, near Camp III, surrounded by mossy montane rainforest at 1,230 m elevation, $22^{\circ} 12^{\prime} 40^{\prime \prime}$ S, $47^{\circ} 00^{\prime} 00^{\prime \prime}$ E, T. Pócs, A. Szabó 9473/K, 22. Sept. 1994 (holotype: TAN; isotypes: G, GOET, EGR, MO, herb. Schäfer-Verwimp). 
Plants in herbarium brownish yellow, creeping on the irrigated granite rock, forming a continuous mat. Stems ca $50 \mu \mathrm{m}$ thick, adherent, irregularly branched, branches to $4 \mathrm{~mm}$ long. Leaves about $1 \mathrm{~mm}$ long, erecto-patent, spreading at an angle of $60-80^{\circ}$ to the stem. Lobes about half of the lobule

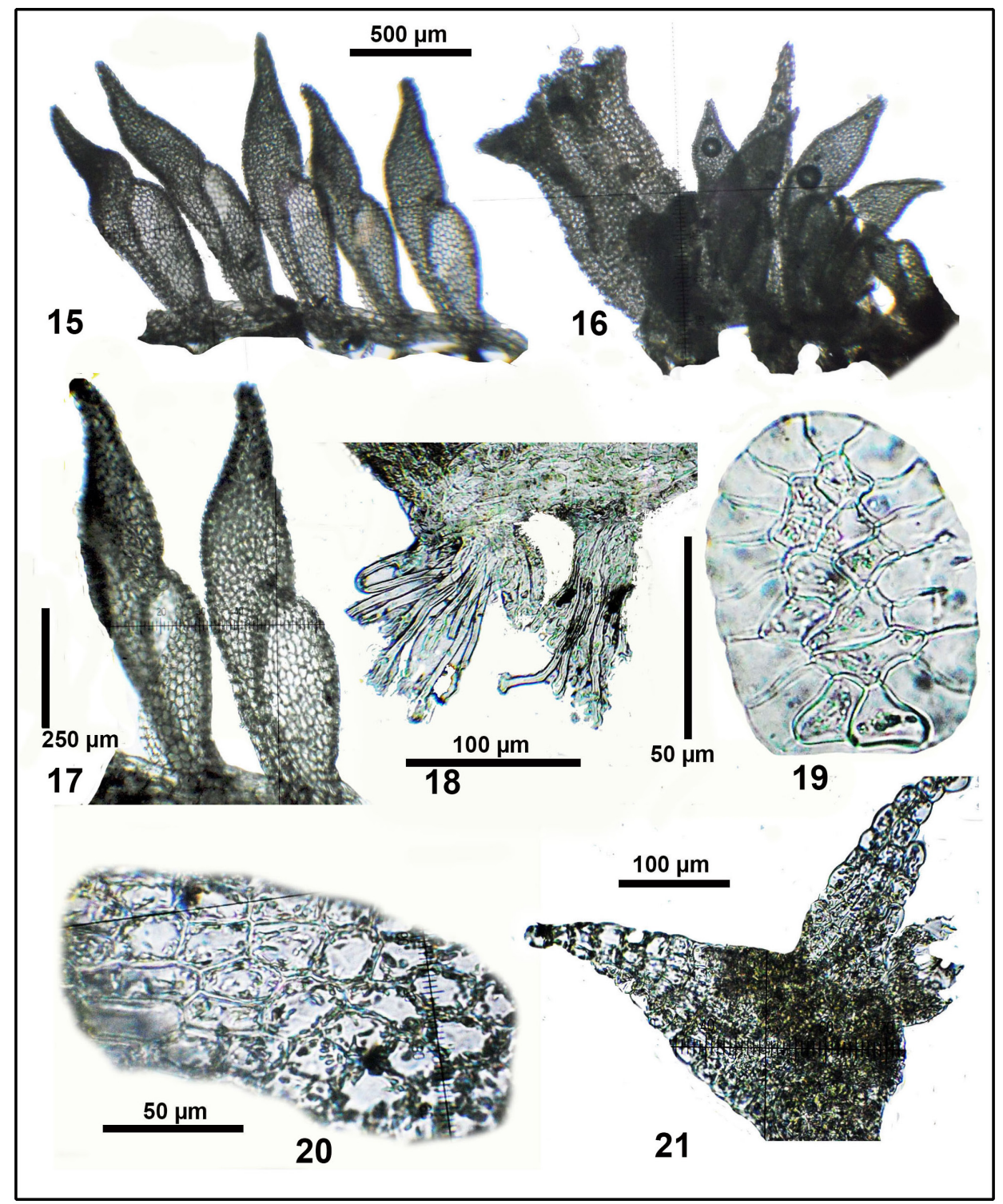

Figs 15-21. Colura cataractarum Pócs, sp. nov. (all from the type): $15=$ habit, side view; $16=$ lant with perianth, side view; 17 = leaves, side view; 18 = rhizoid bundles, side view; $19=$ valve; 20 = lobe cells; $21=$ underleaf 


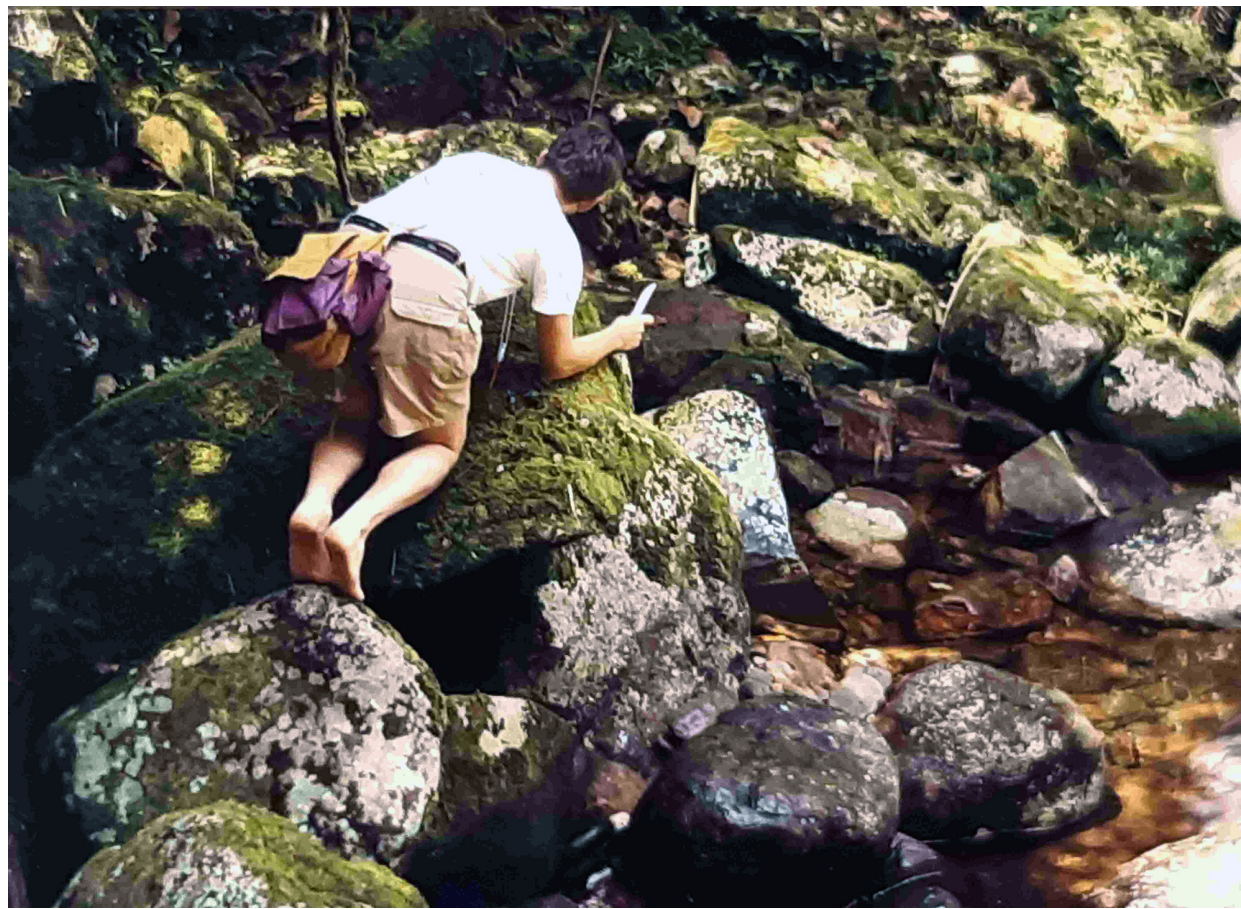

Fig. 22. András Szabó collecting Colura cataractarum at its type locality, from the irrigated granite rocks

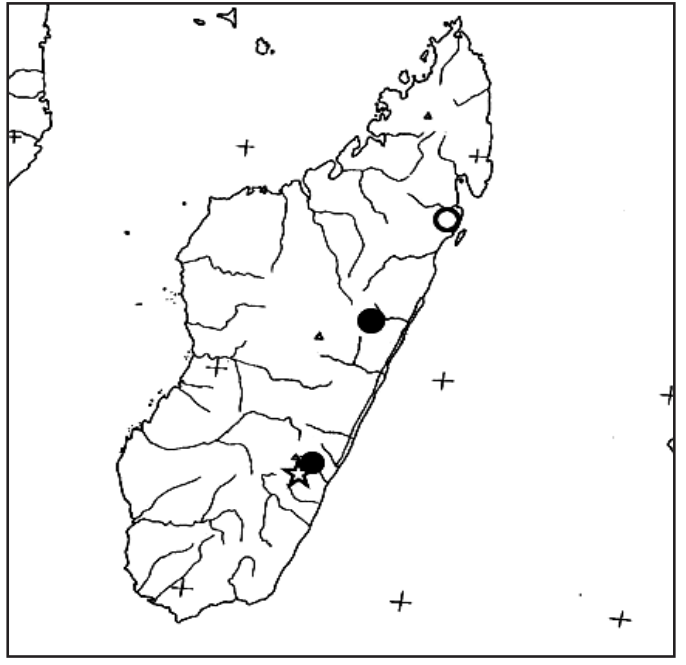

Fig. 23. Endemic species of Madagascar. Star: Colura cataractarum, ring: Colura bicornis. (Here and later: black: known data, white: new records) length, inflated, convolute, about $250 \mu \mathrm{m}$ wide, auriculate at base. Lobules gradually widening above into a hood shaped sac, ca $200 \mu \mathrm{m}$ wide at base and 500-600 $\mu \mathrm{m}$ long, with obtuse apex. Leaf cells irregular polygonal, ca $20 \mu \mathrm{m}$ in diameter, somewhat elongate near the lobe margin, to $40 \mu \mathrm{m}$ long, walls thin, without trigones and intermediate thickenings, outer wall smooth, on the sac mamillosely protruding. Valves ca $75 \times 65 \mu \mathrm{m}$, with 16-17 hyaline marginal and 11-12 median cells, of which the two basal ones are more or less triangular in shape. Underleaves 
$\mathrm{V}$-shaped, to $500 \mu \mathrm{m}$ wide, with triangular lobes, $5-8$ cells wide at their base, ending in a row of 1-2 rounded cells. Rhizoids colourless, unicellular, often ending up in short dichotomy. Gynoecia on very short side branches; female bracts with rounded apex, about $1 / 3$ of the length of the perianth; perianth urn-shaped, up to $1.2 \mathrm{~mm}$ long, without horns $0.5 \mathrm{~mm}$ wide, with 5 horns, the horns broadly triangular, 100-200 $\mu \mathrm{m}$ long, nearly horizontally spreading; beak 1-2 cells (up to $6 \mu \mathrm{m}$ ) high, not emerging. Androecia not seen. Vegetative reproduction by gemmae from the perianth mouth.

Etymology: named for its occurrence on regularly irrigated rock surfaces in a cataract (Fig. 22). This habitat is very rare in the genus Colura and is otherwise known in the morphologically highly unusual C. irrorata (Spruce) Heinrichs, Y. Yu, Schäf.-Verw. et Pócs (= Myriocolea irrorata Spruce) (Gradstein et al. 2004).

\section{DISCUSSION}

Since the publication of World checklist of hornworts and liverworts (Söderström et al. 2016) four new species of Colura have been described, hence the total number of species in this genus, according to our present knowledge, is 86 . The number may change in the future with synonymization and description of further species. A notable feature of the genus is that the greater part of the species is endemic, while several species are worldwide distributed or at least pantropical. This can be the result partly of their quick and steady evolvement since the Cretaceous (Feldberg et al. 2014, Wilson et al. 2007), partly of the ability of many species for vegetative reproduction by mass production of disciform gemmae. These develop in endo- or exogenous ways (Pócs 2012), usually at the upper end of the sacciform lobule and sometimes on the perianth. The gemmae might be more successful in long range dispersal than the large, protonematic spores attaining sometimes $100 \mu \mathrm{m}$ in length in many species (Weiss 2001). The fully developed gemmae of different Colura species have the same diameter $(80-100 \mu \mathrm{m})$, but being lighter and having much larger specific surface due to their shape (Zanten and Pócs 1981) they have a good chance to float in the air. Their survival ability is not yet experimentally checked. It is notable that the autoicous, worldwide distributed Colura calyptrifolia has relatively small, unicellular spores (Jovet-Ast 1954).

Examples of endemic species are the Melanesian endemics (Fig. 23) C. australiensis, C. crispiloba and C. vitiensis Eggers et Pócs (the latter reaching westwards to the Solomon Islands; Pócs 2013), and C. queenslandica B. Thiers, a narrow endemic of Queensland (Thiers 1987). Colura heimii and C. humbertii, hitherto considered endemic to Madagascar and the Mascarene Islands, have become known also from the Nguru Mts of Tanzania (Fig. 24). These two species are joining the group of more than 50 "Lemurian" elements (Pócs 1975, 1982, 1999, 


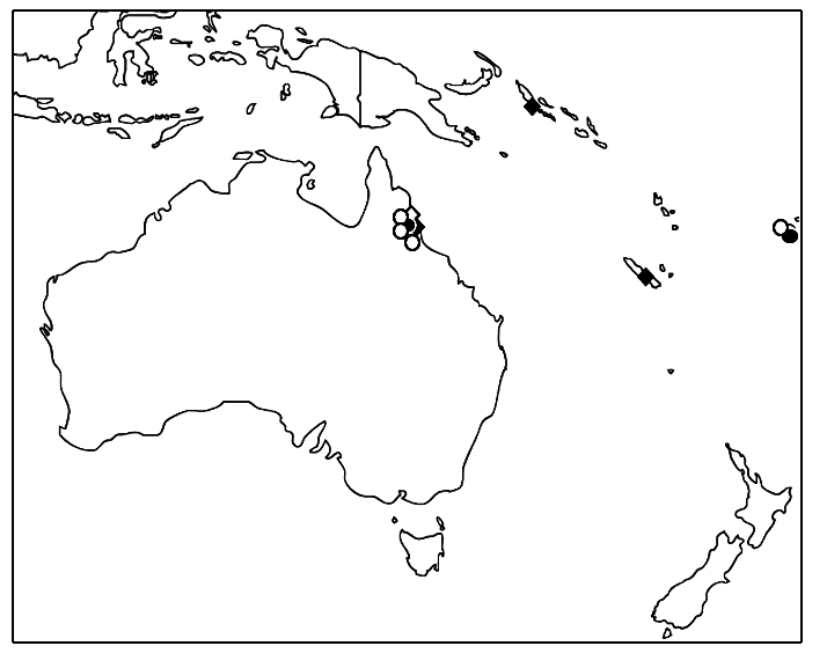

Fig. 24. Distribution of Melanesian species. Diamond: Colura australiensis. - Ring: Colura crispiloba

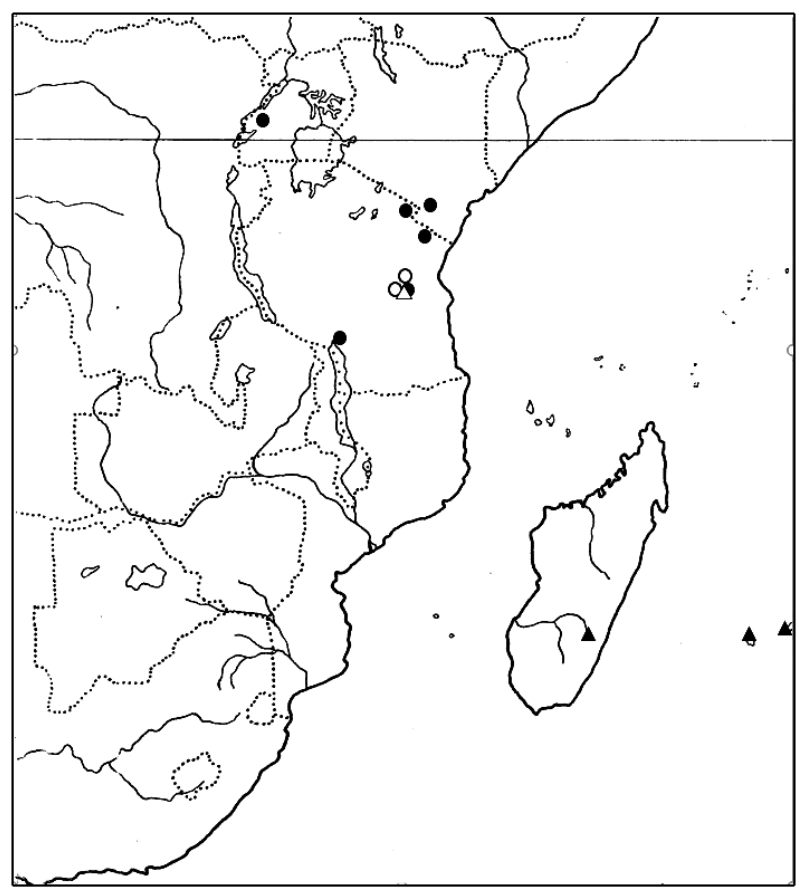

Fig. 25. Distribution of Lemurian (Indian Ocean-East African) species and endemic East African species. Triangle: Colura humbertii. - Ring: Colura saroltae
2000, Tixier 1978) occurring in Madagascar and the crystalline Eastern Arc mountain range of mainland Africa, extending from southern Kenya to southern Tanzania.

The new species, $C$. cataractarum, represents a small group within section Colura characterised by the hood-like, relatively wide conical sac, approaching morphologically the sect. Oidocorys. In fact, these two sections, characterised by their valves with 2 triangular basal-median cells (Grolle and Zhu 2002), represent related, sister lineages within the subgenus Colura, separated from the sect. Harmophyllum (Heinrichs et al. 2012). Colura cataractarum seems to be a narrow endemic of Madagascar, similarly in distribution to C. bicornis (Fig. 22).

The Andringitra Massif, where the new species was found, is particularly rich in endemics compared with other Madagascar localities, and several new bryophyte taxa have recently been described from this area. Examples of rare taxa of this area include Amazoopsis diplopoda (Pócs) J. J. 
Engel et G. L. Merr., Ceratolejeunea andringitrae Pócs, Cheilolejeunea cordigera (Steph.) Grolle, Colura bicornis Ast, Diplasiolejeunea andringitrae Schäfer-Verw., D. ornata Pócs et Schäfer-Verw., Otolejeunea moniliata Grolle in Tixier, Plagiochila angusta Lindenb., Serpotortella chenagonii (Ren. et Card.) Vitt et Zander and Heteroscyphus grandistipus (Steph.) Schiffn. (Fig. 14), the latter growing on tree-fern stems and decaying logs in mossy montane rainforest (Pócs 9473/AF, EGR, TAN). This species is new to Madagascar, hitherto being known only from Zimbabwe (Sim 1926) and Réunion (Ah-Peng et al. 2012). A good illustration of the species is available in the Icones of Stephani (1985: 1833).

As the new records of the Colura species have demonstrated, the ranges of the species of this large genus are still very imperfectly known. To obtain a more precise picture, many more specimens have to be studied by morphotaxonomic and molecular methods.

Acknowledgements - I wish to express thanks for the financial support of collecting trips to the Australian Biological Resources Study Participatory Programme, the National Geographic Society (USA), the Missouri Botanical Garden and the ALCOA Foundation (USA), the Swedish-Hungarian-Tanzanian Usambara Rainforest Program sponsored by the SAREC agency and coordinated by professor Olov Hedberg from the Uppsala University, the Hungarian Scientific Research Fund OTKA, the Hungarian Academy of Sciences and the Hungarian Ministry of Education and Culture. I am very grateful to my collecting companions as the late Heinar Streimann, Robert E. Magill, Danielle Florins, Catherine LaFarge-England and my late wife Sarolta, Gabriella Kis, Andrea Sass-Gyarmati, Sándor Orbán, András Szabó and András Vojtkó and to our Malagasy guide in the Andringitra Massif, Rzafindrabe Jean-Baptiste de la Salle from the Tsimbazaza Botanical and Zoological Garden (Antananarivo). Finally, I am very thankful for the careful corrections and amendments made by my reviewers, prof. S. Robbert Gradstein and Alfons Schäfer-Verwimp.

\section{REFERENCES}

Ah-Peng, C. and Bardat, J. (2005): Checklist of the bryophytes of Reunion Island (France). Bryoph. Div. Evol. (Trop. Bryol.) 26: 89-118. https://doi.org/10.11646/bde.26.1.14

Ah-Peng, C., Bardat, J., Ellis, L., Hedderson, T., Malombe, I., Matcham, H., Pócs, T., Porley, R., Seneca, A., Söderström, L. and Wilbraham, J. (2010a): Additions to the bryoflora of Reunion Island 3: new and interesting records from the Tropical Bryology Group (British Bryological Society). - J. Bryol. 32: 288-295. https://doi.org/10.1179/03736681 0x12814321877624

Ah-Peng, C., Bardat, J., Stamenoff, P., Hedderson, T. A. J. and Strasberg, D. (2010b): Bryophytes de l'ile de La Réunion: diversité, endemicité et conservation. - Cryptogamie, Bryol. 31: 241-270.

Ah-Peng, C., Bardat, J., Pócs, T., Söderström, L., Staménoff, P. and Strasberg, D. (2012): Red list of liverworts and hornworts for Réunion (Mascarene archipelago). - Phytotaxa 68: 1-23. https://doi.org/10.11646/phytotaxa.68.1.1 
Eggers, J., Infante, M. and Heras, P. (2004): New bryophyte taxon records for tropical countries 5. - Bryoph. Div. Evol. (Trop. Bryol.) 25: 19-23. https://doi.org/10.11646/bde.25.1.4

Enroth, J., Pócs, T., He, X.-L., Nyqvist, P., Stam, Å., Malombe, I. and Rikkinen, J. (2019): An annotated checklist of the bryophytes of Taita Hills region, Kenya. - Acta Mus. Siles. Sci. Natur. 68: 53-66. https://doi.org/10.2478/cszma-2019-0007

Feldberg, K., Schneider, H., Stadler, T., Schäfer-Verwimp, A., Schmidt, A. R. and Heinrichs, J. (2014): Epiphytic leafy liverworts diversified in angiosperm-dominated forests. Sci. Reports 4/5974: 1-6. https://doi.org/10.1038/srep05974

Fischer, E. (2013): Liverworts and hornworts of Rwanda. - Abc Taxa 14: 1-551.

Gradstein, S. R. (1997): Hepatophyta. - In: Boggan, J., Funk, V., Kelloff, C., Hoff, M., Cremers, G. and Feuillet, C. (eds): Checklist of the plants of the Guianas. 2nd ed. University of Guyana, Georgetown, Guyana, pp. 9-15.

Gradstein, S. R., Pócs, T. and Váňa, J. (1984): Disjunct Hepaticae in tropical America and Africa. - Acta Bot. Hung. 29: 127-171.

Gradstein, S. R., Reiner-Drehwald, M. E. and Jost, L. (2004): The systematic position and distribution of Myriocolea irrorata (Lejeuneaceae), an endangered liverwort of the Ecuadorian Andes. - J. Hattori Bot. Lab. 95: 235-248.

Grolle, R. (1995): The Hepaticae and Anthocerotae of the East African Islands. An annotated catalogue. - Bryophyt. Bibl. 48: 1-178.

Grolle, R. and Zhu, R. L. (2002): On Macrocolura and the subdivision of Colura (Lejeuneaceae, Hepaticae). - J. Hattori Bot. Lab. 92: 181-190.

Heinrichs, J., Dong, Sh., Yu, Y., Schäfer-Verwimp, A., Pócs, T., Feldberg, K., Hentschel, J., Schmidt, A. R. and Schneider, H. (2012): A 150 year-old mystery solved: Transfer of the rheophytic endemic liverwort Myriocolea irrorata to Colura. - Phytotaxa 66: 55-64. https://doi.org/10.11646/phytotaxa.66.1.9

Hürlimann, H. (1987): Hepaticae aus dem Gebiete des südlichen Pazifik IX. - Bauhinia 8(4): 221-234.

Jones, E. W. (1958): A provisional key to the genera of tropical African hepatics. - J. W. African Sci. Assoc. 4: 50-73.

Jones, E. W. (1979): African Hepatics XXXI. Rare or little-known Lejeuneaceae and extensions of range. - J. Bryol. 10: 387-400. https://doi.org/10.1179/jbr.1979.10.4.387

Jones, E. W. and Pócs, T. (1987): African hepatics. XXXVI. Three new species of Colura. - J. Bryol. 14(3): 495-501. https://doi.org/10.1179/jbr.1987.14.3.495

Jovet-Ast, S. (1954): Le genre Colura, Hépatiques. Lejeuneaceae, Diplasiae. - Rev. Bryol. Lichénol. 22: 206-312. (1953).

Jovet-Ast, S. (1956): Deux Colura nouveaux de Madagascar. - Rev. Bryol. Lichénol. 25: 272276.

Jovet-Ast, S. (1958): Localités nouvelles de diverses espèces du genre Colura. - Rev. Bryol. Lichénol. 27: 19-23.

Jovet-Ast, S. (1976): Compléments à la connaissance des Colura: espèce et localités nouvelles. - Rev. Bryol. Lichénol. 42: 909-922.

Jovet-Ast, S. (1983): Colura nouveaux d'origines diverses (Hépatiques, Lejeuneacées). Cryptogamie, Bryol. Lichénol. 4(3): 205-216.

Marline, L., Andriamiarisoa, R. L., Bardat, J., Chuah-Petiot, M., Hedder-son, T. A. J., Reeb, C., Strasberg, D., Wilding, N. and Ah-Peng, C. (2012): Checklist of the bryophytes of Madagascar. - Cryptogamie, Bryol. 33(3): 199-255. https://doi.org/10.7872/cryb.v33. iss3.2012.199 
McCarthy, P. M. (2003): Catalogue of Australian liverworts and hornworts. - Flora of Australia Supplementary Series 21. Australian Biological Resources Study, Canberra, 137 pp.

Mustelier Martínez, K. (2005): Appendix 1. Especies de hepáticas registradas en el Parque Nacional "Alejandro de Humboldt". - Rapid boil. invent. 14: 220-227.

Pócs, T. (1975): Affinities between the bryoflora of East Africa and Madagascar. In: Miège, J. and Stork, A. (eds): Origines des flores africaines et malgaches. Nature, spéciation. Comp.-rend. de la VIIIe réunion de l'AETFAT, 1. - Boissiera 24a: 125-128.

Pócs, T. (1982): Examples of the significance of historical factors in the composition of bryofloras. - Beih. Nova Hedwigia 71: 303-309.

Pócs, T. (1991): The genus Colura in East Africa. - Bull. Brit. Bryol. Soc. 57: 33-39.

Pócs, T. (1994): The altitudinal distribution of Kilimanjaro bryophytes. - In: Seyani, J. H. and Chikuni, A. G. (eds): Proceedings of the XIIth Plenary Meeting of AETFAT. Zomba, Malawi, 2-11 April 1991, 2: 797-812.

Pócs, T. (1995): East African Bryophytes, XIV. Hepaticae from the Indian Ocean Islands. Fragm. Flor. Geobot. 40: 251-277.

Pócs, T. (1999): Bryophyte speciation and diversity in the East African mountains. - Bryobrothera 5: 237-245.

Pócs, T. (2000): Bryophyte diversity along the Eastern Arc. - J. East African Nat. Hist. 87: 75-84. (1998).

Pócs, T. (2010): East African Bryophytes, XXVI. New records from Mayotte (Maore) Island (French Comoro). - Acta Bryolich. Asiatica 3: 105-114.

Pócs, T. (2012): Endogenous gemmae in certain Lejeuneaceae (Marchantiophyta). - Int. J. Plant Repr. Biol. 4(2): 101-105.

Pócs, T. (2013): The genus Colura (Lejeuneaceae) in New Guinea and in the neighboring areas. - Chenia 11: 12-38.

Pócs, T. (2015): Contribution to the bryoflora of Australia, V. Colura streimannii sp. nov. from Queensland. - Polish Bot. J. 60(1): 7-11. https://doi.org/10.1515/pbj-2015-0006

Pócs, T. (2019): New liverworts from the Peruvian Andes. I. Colura ochyrana and Drepanolejeunea halinae (Lejeuneaceae, Marchantiophyta). - Acta Mus. Siles. Sci. Natur. 68: 37-44. https://doi.org/10.2478/cszma-2019-0005

Pócs, T. and Eggers, J. (2007): Bryophytes from the Fiji Islands, II. An account of the genus Colura, with the description of C. vitiensis sp. nov. - Polish Bot. J. 52(2): 81-92.

Pócs, T. and Streimann, H. (2006): Contributions to the bryoflora of Australia, I. - Bryoph. Div. Evol. (Trop. Bryol.) 27: 19-24. https://doi.org/10.11646/bde.27.1.4

Pócs, T. and Váňa, J. (2015): East African Bryophytes XXX. New liverwort and hornwort records. - Acta Biol. Plant. Agriensis 3: 3-21.

Pócs, T., Müller, F. and Shevock, J. R. (2015): Additions to the liverwort and hornwort flora of São Tomé and Príncipe II, with Neurolejeunea, a genus new to Africa. - Herzogia 28(1): 50-69. https://doi.org/10.13158/heia.28.1.2015.50

Schäfer-Verwimp, A. (1999): Some additions to the Bryophyte Flora of Dominica, West Indies. - Haussknechtia Beih 9: 317-331.

Schäfer-Verwimp, A. and van Melick, H. M. H. (2016): A contribution to the bryophyte flora of Jamaica. - Cryptogamie, Bryol. 37(3): 305-348. https://doi.org/10.7872/cryb/ v37.iss3.2016.305

Sim, T. R. (1926): The Bryophyta of South Africa. - Trans. Roy. Soc. South Africa 15: 1-475.

Söderström, L., Hagborg, A., Pócs, T., Sass-Gyarmati, A., Brown, E., von Konrat, M. and Renner, M. (2011): Checklist of hornworts and liverworts of Fiji. - Telopea 13: 405-454. 
Söderström, L., Hagborg, A., von Konrat, M., Bartholomew-Began, Sh., Bell, D., Briscoe, L., Brown, E.t, Cargill, D. C., Costa, D. P., Crandall-Stotler, B. J., Cooper, E. D., Dauphin, G., Engel, J. J., Feldberg, K., Glenny, D., Gradstein, S. R., He, X., Heinrichs, J., Hentschel, J., Ilkiu-Borges, A., Katagiri, T., Konstantinova, N. A., Larraín, J., Long, D. G., Nebel, M., Pócs, T., Puche, F., Reiner-Drehwald, E., Renner, M. A. M., SassGyarmati, A., Schäfer-Verwimp, A., Segarra, J. G. M., Stotler, R. E.t, Sukkharak, Ph., Thiers, B. M., Uribe, J., Váňa, J., Villareal, J. C., Wigginton, M., Zhang, L. and Zhu, R. L. (2016): World checklist of hornworts and liverworts. - PhytoKeys 59: 1-828. https:// doi.org/10.3897/phytokeys.59.6261

Stephani, F. (1916): Species hepaticarum 5. - George \& Cie, Genève \& Bâle, pp. 833-1008. https://doi.org/10.5962/bhl.title.95494

Stephani, F. (1985): Icones Hepaticarum. - Jardin Botanique de Genève, Zug, 12315 pp. (165 microfiches).

Thiers, B. M. (1987): A preliminary account of Colura (Hepaticae, Lejeuneaceae) in Australia. - Brittonia 39(2): 175-179.

Tixier, P. (1978): La spéciation lemurienne et les Lejeuneacées. Le cas du genre Diplasiolejeunea. - In Suire, C. (ed.): Congrés International de Bryologie, Bordeaux, 21-23 Novembre 1977, Comptes Rendus. - Bryophyt. Bibl. 13: 622-645.

Weiss, G. (2001): Morphologische und anatomische Untersuchungen der Sporophyten bei Jubulaceae Klinggr. und Lejeuneaceae Casares-Gil (Hepaticae) und deren systematische Bedeutung. - Bryophyt. Bibl. 57: 1-302.

Wigginton, M. J. (2018): Checklist and distribution of the liverworts and hornworts of subSaharan Africa, including the East African Islands (ed. 4, 25 June 2018). - Trop. Bryol. Res. Reports 9: 1-138.

Wilson, R., Heinrichs, J., Hentschel, J., Gradstein, S. R. and Schneider, H. (2007): Steady diversification of derived liverworts under Tertiary climatic fluctuations. - Biol. Lett. 3: 566-569. https://doi.org/10.1098/rsbl.2007.0287

Zanten, B. O. and Pócs, T. (1981): Distribution and dispersal of bryophytes. - In: SchultzeMotel, W. (ed.): Advances in Bryology 1. J. Cramer, Vaduz, pp. 479-562.

Open Access statement. This is an open-access article distributed under the terms of the Creative Commons Attribution 4.0 International License (https://creativecommons.org/ licenses/by/4.0/), which permits unrestricted use, distribution, and reproduction in any medium, provided the original author and source are credited, a link to the CC License is provided, and changes - if any - are indicated. (SID_1) 